\title{
Estimation of Benefits and costs of Korea's unification: A critical Review
}

\author{
Inkyo Cheong*
}

\section{Summary}

Discussion of unification was for several decades focused on the costs rather than the benefits for Korea, until reports emphasizing the latter were published by Goldman Sachs (2009) and various Korean think tanks over the past four to five years. Although these studies can be evaluated positively in pointing out the benefits of unification rather than the concerns about the costs, several questions can be raised. This paper tries to evaluate the quality and credibility of existing studies and suggests a new approach for estimating the impact of unification. It proposes a computational general equilibrium (CGE) model to be based on the social accounting matrix (SAM) and input-output (IO) table for the North Korean economy, in order to produce more reliable estimates of the benefits and costs of unification and the impact of various cooperative activities between the two Koreas.

Key Words: Unification of Korea, benefits and costs of unification, IO table of North Korea JEL classifications: P33, C67, D57

\footnotetext{
* This work was supported by INHA UNIVERSITY Research Grant and a research grant by Jungseok Research Institute for International Logistics and Trade. The author thanks anonymous commentators for their valuable comments on this paper. The usual disclaimer applies.
} 


\section{Introduction}

At a 2014 New Year press conference, President Park Geun-hye of South Korea delivered a speech focusing on the merits of the unification of Korea, predicting that the country would collect huge economic gains amounting to daebak (a big economic windfall or hitting the "economic jackpot"). This could affect the attitude of Koreans toward inter-Korean unification, considering that unification costs have been widely regarded as the main issue so far. Although Koreans recognize that unification is the greatest challenge for their generation, it has not been clear to them whether it will be a blessing (an "economic jackpot") or an additional serious national burden in supporting the per capita income of North Korean residents and building social infrastructure.

A Unification Preparation Committee was organized by the government in mid-2014, about six months after the President's remarks, with its main duty being to discuss various issues regarding inter-Korean unification. Most of its members are experts on diplomatic and political issues, with a supporting group of government officials and think tank researchers. Several criticisms have been raised regarding human structure of this committee. Some of the issues raised are that its role and purposes are too vague and that no clear group of experts exists to examine issues related to economic integration and realizing any possible economic "jackpot." Its functions could also overlap with those of many other national organizations. ${ }^{1)}$

For several decades, discussion and research on unification was focused on the costs rather than the benefits for Korea. However, after Goldman Sachs published a report in 2009 on the benefits of unification, national think tanks such as the Korea Institute of International Economic Policy (KIEP) began to focus on these positive aspects. While their studies make a contribution in considering more than just the cost concerns about unification, several questions can be raised about this research. This paper tries to evaluate the quality and credibility of these studies and suggests a new approach for estimating the benefits and costs of unification.

1) The Ministry of Unification, Korea Institute for National Unification, and the Advisory Council on Democratic and Peaceful Unification have similar functions. 


\section{Existing Studies on the costs and Benefits of Korean Unification}

\subsection{Summary of Existing Studies}

There exists a wide range of estimates on the costs of unification from Korean and foreign economists. After the process of German unification following the collapse of the Berlin Wall in 1989, economists commenced studying the costs of Korean unification in the 1990s. Lee (1994), Jung (1996), and Nol and et al. (1997) are examples of early studies. Many studies were undertaken over the past decade, but no progress was made in the methodology of estimation.

Most of these previous studies contain estimation problems through their failure to consider the method of unification, unification processes, and the dynamic development of an integrated economy (Lee and Kim, 2012). The wide range of estimated costs in itself has made Korean people more pessimistic toward unification, apart from the generally high estimates themselves. For example, drawing from the experience of the German unification process, Choi (2011) estimated that $10-12 \%$ of South Korea's GDP would be required for 10 years after unification to raise the income level of North Korean people to $80-90 \%$ of that of South Koreans.

The total cost estimated by Korea Development Institute (KDI, 2010) was US\$322 billion for 2011-2040 under the assumption of a gradual unification, which rises to US\$2 trillion 140 billion for 30 years after unification should North Korea collapse suddenly. Wolf (2010) estimated US\$1 trillion 700 billion to be expended in improving the North Korean economy to a stage similar to that of South Korea and US\$62 billion in doubling North Korea's per capita income. The estimates by Beck (2010) were US\$2 trillion in increasing North Koreans' per capita income to $80 \%$ of that of South Koreans over 3 decades, which rises to US\$3-5 trillion in the worst case.

Table 1.

Examples of Existing Studies on the costs of Unification

\begin{tabular}{c|c|c}
\hline Author & Target income, assumptions & Estimates of unification costs \\
\hline Lee, Youngsun (1992) & $\begin{array}{c}60 \% \text { of South Korea's (SK) } \\
\text { economy for 40 50 years after } \\
\text { unification }\end{array}$ & $\begin{array}{c}\text { US\$841 billion for 40 50 years } \\
\text { after unification }\end{array}$ \\
\hline
\end{tabular}




\begin{tabular}{|c|c|c|}
\hline Author & Target income, assumptions & Estimates of unification costs \\
\hline Park, Suksam (2003) & $\begin{array}{l}\text { Costs of investment for NK } \\
\text { social and economic } \\
\text { infrastructure }\end{array}$ & $\begin{array}{c}\text { Gradual unification: } 870 \text { billion } \\
\text { Korean Won (KRW) per year } \\
\text { Sudden collapse: } 35 \text { trillion } \\
\text { KRW per year }\end{array}$ \\
\hline RAND (2005) & $\begin{array}{l}\text { Total cost for achieving NK } \\
\text { income up to par that of SK }\end{array}$ & $\begin{array}{c}\text { 60 795 trillion KRW for } 5 \\
\text { years after unification }\end{array}$ \\
\hline SERI (2005) & $\begin{array}{l}\text { Support } 10 \% \text { of NK GDP for } \\
\qquad 2015 \sim 2025\end{array}$ & $\begin{array}{c}\text { Total } 546 \text { trillion KRW for } 10 \\
\text { years }\end{array}$ \\
\hline Shin, Changmin (2010) & $\begin{array}{c}\text { Additional unification cost } \\
\text { when the unification is delayed }\end{array}$ & $\begin{array}{l}\text { US\$616.1 billion for } 10 \text { years } \\
\text { after unification ( } 2010 \text { year) }\end{array}$ \\
\hline Beck, Peter (2010) & $\begin{array}{l}80 \% \text { of SK economy. Costs for } \\
30 \text { years }\end{array}$ & $\begin{array}{c}\text { German: US\$2 trillion } \\
\text { Vietnam/Yemen (war) : 3 5 } \\
\text { trillion US\$ }\end{array}$ \\
\hline Wolf(2010) & $\begin{array}{l}\text { Total cost for achieving NK } \\
\text { income up to par that of SK }\end{array}$ & US $\$ 1.70$ trillion \\
\hline $\begin{array}{c}\text { KDI } \\
(2010)\end{array}$ & $\begin{array}{l}\text { Total cost for achieving NK } \\
\text { income up to par that of SK for } \\
\text { 2011 2040 }\end{array}$ & $\begin{array}{l}\text { Gradual unification: US\$322 } \\
\text { billion for } 30 \text { years } \\
\text { Sudden collapse: US\$2.140 } \\
\text { trillion for } 30 \text { years }\end{array}$ \\
\hline Cho, Dongho (2010) & $\begin{array}{l}\text { Costs of investment for NK } \\
\text { social and economic } \\
\text { infrastructure }\end{array}$ & $6 \sim 14 \%$ of SK GDP \\
\hline Choi, Junwook (2011) & $\begin{array}{c}\text { Total cost for achieving NK } \\
\text { income up to par } 80-90 \% \text { of SK } \\
\text { for } 50 \sim 60 \text { years after } \\
\text { unification }\end{array}$ & $\begin{array}{c}7 \sim 12 \% \text { of SK GDP for } 10 \text { years } \\
\text { after unification ( } 2008 \text { year, } \\
122 \text { trillion KRW) }\end{array}$ \\
\hline KINU (2011) & $\begin{array}{c}\text { Costs of transforming NK into } \\
\text { market economy }\end{array}$ & $\begin{array}{c}5 \text { trillion KRW } \sim 22 \text { trillion } \\
\text { KRW for } 20 \text { years. } 3 \sim 7 \text { times } \\
\text { the unification costs of } \\
\text { Germany (exchange rate, price } \\
\text { level) }\end{array}$ \\
\hline Lee·Kim (2012) & $\begin{array}{l}\text { Costs of investment in NK } \\
\text { social and economic } \\
\text { infrastructure }\end{array}$ & $\begin{array}{c}\text { Qualitative assessment, not } \\
\text { quantitative }\end{array}$ \\
\hline
\end{tabular}

Source: Summary by the author 
Kim (2014) presented a more elaborate and balanced argument in estimating the costs of unification by considering the likely benefits from expanded markets due to an integrated economy and a boom in economic activity over time after unification, although chaotic social and economic conditions are inevitable. Kim and et al. (2008) analyzed the dynamic evolution of transitional countries after the collapse of the Berlin Wall, arguing that more detailed research on the process of such transited economies is required, and that economic reform and liberalization in North Korea will be key in reducing the costs of unification and smoothing the unification process.

Most of the existing economic studies regarding inter-Korean unification are estimations of the costs of unification benchmarked by the experience of German unification. Depending on the assumptions made as to the unification scenario and economic data for North Korea, estimates of the costs of unification range from US\$73.2 billion (Lee, 2003) to a maximum of US\$5 trillion when assuming a war such as in the case of Yemen (Beck, 2010). However, recent studies present the benefits of unification as outweighing the costs. Goldman Sachs (2009) reports US\$1 trillion gains for South Korea based on the synergistic effects of South and North economies after unification. Sung (2014) estimates that unification would bring 16\% GDP growth for North Korea during 2016-2030 annually and 1\%p GDP growth for South Korea in the same period.

\subsection{Benefit and cost Factors of Unification}

The benefits and costs of unification will be substantially different depending on critical factors such as the method of unification. In the case of a sudden collapse of North Korea, it is not easy to pre-estimate the costs of unification, since the situation after collapse is not foreseeable and could be changed by several factors. Economic problems such as a shortage of necessities will be a basic issue, but many social and political problems including refugees will emerge. Although previous experiences such as German unification can act as a reference, it is difficult to imagine that a similar unification process will occur in Korea.

Although unification is one of most important values for Koreans, an economically efficient transition is desirable for the Korean people as well as the whole Korea, considering the burden of unification costs from chaos and the current economic situation, which is growing slowly. The fact that there is no consensus as to the estimated costs of unification makes it difficult for Koreans to judge the value of unification. While the many factors involved in estimating the costs of unification under various scenarios render the process complex, a lack of information about the North Korean economy has been a major 
reason for the lack of progress in estimating the costs of unification.

Although optimistic prospects for unification have been raised recently, these estimates are substantially affected by the unification scenarios. No concrete data and information on the economy of North Korea are available. Unification and economic integration require a long-term process to be implemented in stages. German unification has taken longer than two decades, and it is indeed still in progress. Thus, Korean unification cannot be accomplished all at once; it demands a substantial length of time and extensive diplomacy. Sung (2014) assumes that many young men will be discharged from the military forces of both Koreas and they will reinforce the labor supply in industrial sectors, contributing to economic growth. However, the study does not investigate whether the industrial base in North Korea has the capacity to accommodate more workers in terms of aspects such as technology, logistics, energy, and markets.2)

Whether North Korea has the capacity to produce marketable products is not clear. How rapidly the North Korean economy can be transformed into a market system will be a critical element in determining the benefits and costs of unification. More specifically, in order to export products, North Korea will require access to foreign markets. The assumption is made that if South Korea's economic system and practices are extended into North Korea, and all their legal and economic systems are integrated after unification, no trade issues regarding exports by North Korea will arise. This is too optimistic and is not realistic in many aspects. Social and political turmoil will work against the benefits of unification. It should be emphasized that unification cannot be realized overnight and that no "master plan" prepared in advance will be workable.

Economic integration preceded political integration in Germany. Immediately after Germany was divided into East and West, both parties began to trade with each other under the heading of internal German trade; production cooperation began00 in 1960. Negotiations were undertaken 34 times on science, technology, culture, environment, among others, during the 15 years between 1972 and 1987. East Germany was one of the more advanced industrial countries of Eastern Europe and had well-trained human resources. The per capita income of East Germany was US\$6,749, the highest recorded among socialist countries. Industrial bases in East Germany were organized in provincial administration units (Kombinat) and goods produced under the socialist planning system were allocated through a distribution system (Handelsorganisation). East Germany's international trade was divided between socialist countries and market economies in the ratio 2:1, and more than $90 \%$ of its overall trade was with Russia (Soviet Union) and West Germany. West Germany accounted for the lion's share of East Germany's trade with

2) Regarding poor infrastructure in North Korea, refer to BusinessKorea(2015). 
market economies, but its dealings with East Germany comprised less than 2\% of West Germany's total trade. As its neighboring socialist economies worsened and trade deficits widened, East Germany came to depend more heavily on West Germany.

Table 2.

Trade share of East Germany in the 1980s

\begin{tabular}{l|c|c|c|c}
\multicolumn{7}{|c|}{} & $\begin{array}{c}\text { Allsocialist } \\
\text { countries }\end{array}$ & (Russia) & $\begin{array}{c}\text { Entire market } \\
\text { economy }\end{array}$ & (West Germany) \\
\hline share & 66 & 64 & 34 & 28.4 \\
\hline
\end{tabular}

Source: Park, Sungjo(2014)

Although Germany spent US\$2 trillion for its unification, it was able to save costs due to favorable international conditions when the Berlin Wall collapsed, since the economic system of East Germany was similar to that of a market economy due to its support by West Germany. It is difficult to accept that Korea should anticipate such a situation will exist. Before the World Trade Organization (WTO) was launched in 1995, multilateral trading rules were generally much less stringent under the General Agreement on Tariffs and Trade (GATT) than that of the WTO. External economic issues will certainly be raised by foreign partner countries and international organizations such as the WTO. No one can be sure that South Korea's international status, such as WTO membership, will automatically be extended to North Korea. In many aspects of international trade, the current situation for North Korea is thus different from that of German unification, where the economic system of East Germany was almost compatible with GATT through its support by West Germany, although the former was a socialist country.

It is worth discussing North Korea's economic laws, focusing briefly on their non-market elements. As a socialist country that is controlled by the planning agency in a central party, North Korea does not have a systemic legal infrastructure and the degree of codification of its common law is low, compared with other countries. Its laws have the characteristics of symbolic declarations that do not target rulings for specific cases. Moreover, guidelines laid down by its leaders are regarded as the highest rules for citizens and government officials; the laws can thus effectively be changed by remarks made by these leaders. This implies that North Korea's system of rule violates the principle of constitutionalism. The fact that its laws are regarded as political measures is likely to damage the objectivity and fairness of its legal system in terms of constitutional rule.

The legal framework governing North Korea's external economic affairs comprises 54 
laws including regulations for foreign investment, economic zones, customs, economic contracts, trade processes, rules of origin, and intellectual property rights.3) Although it has a legal system for external business, many elements of its laws are incompatible with those of a market system. The North Korean economy is based on a planned economic system (Article 34 of the North Korean constitution), with which its laws on trade abide. Trade contracts are made according to the planned economic system (article 5 of the law on trade) and the government is supposed to mediate all international trade. While private economic activity is permitted domestically as a small part of the North Korean economy, international trade is only permitted by governmental agencies or organizations and not by private people. In addition, private companies are not permitted in North Korea. Based on these facts, it can be said that North Korea's legal system is fundamentally different to a market economic system with regard to international trade.

\section{Critical Review of Studies of the Benefits of Unification}

\subsection{Studies by Goldman Sachs and KIEP}

It is possible for researchers to estimate the costs of unification using several approaches that range from a target income method to a computational general equilibrium (CGE). An example of a simple approach would be to set a target income for the North Korean people, with additional considerations for building basic infrastructure in North Korea. Estimates of this kind can be found in Beck (2010), Choi (2011), and Lee and Kim (2012). Studies of Korean unification costs using a CGE model include those of Noland (1996), Noland and et al. (1998), Korea Institute of Unification (2011), and KIEP (2014).

KIEP (2014) tries to incorporate aspects such as the growth of production factors (land, labor, and capital) and market expansion due to unification using a CGE model. In case of labor, the study assumes that more workers will be available due to a reduction in the number of military personnel, leading to an improvement in the productivity of North Korean workers when the two countries are united. The study adopts several scenarios in which the North, as part of a united Korea, joins several free trade agreements (FTAs) including the Trans-Pacific Partnership (TPP). It predicts that Korea will enjoy about 3\% GDP growth 20 years after unification, supporting the current government's proposition that unification will be beneficial for the country, although the estimates obtained do not

3) The laws can be found at the Information Center on North Korea (under Korea's Ministry of Unification), which can be accessed at http://library.unikorea.go.kr/search/DetailView.ax?sid=1\&cid=225395 
show "economic jackpot".

Since KIEP is a national think tank that supports policy formulation and collaborates with policy makers, the impact of its findings on a specific issue tends to be critical in Korea. Since Goldman Sachs (2009) reported that unification would bring significant economic gains for Korea rather than a burden in supporting the North Korean people, Korean opinion leaders became interested in the background for Goldman Sachs' optimistic viewpoint. Goldman Sachs (2009) projects that: "The GDP of a united Korea in USD terms could exceed that of France, Germany, and possibly Japan in 30-40 years, should the growth potential of North Korea, notably its rich mineral wealth, be realised." (Goldman Sachs 2009, p.1) "We [Goldman Sachs] believe that the integration costs of South and North Korea could be reduced to an affordable level, if backed by appropriate polices ... We estimate that output growth and currency appreciation under the flexible rate regime, together with annual transfers of $1 \%$ of GDP from the South, could shorten the time needed to reach half the income level of South Korea to 13 years" (Goldman Sachs 2009, p.20), as illustrated in Figure 1.

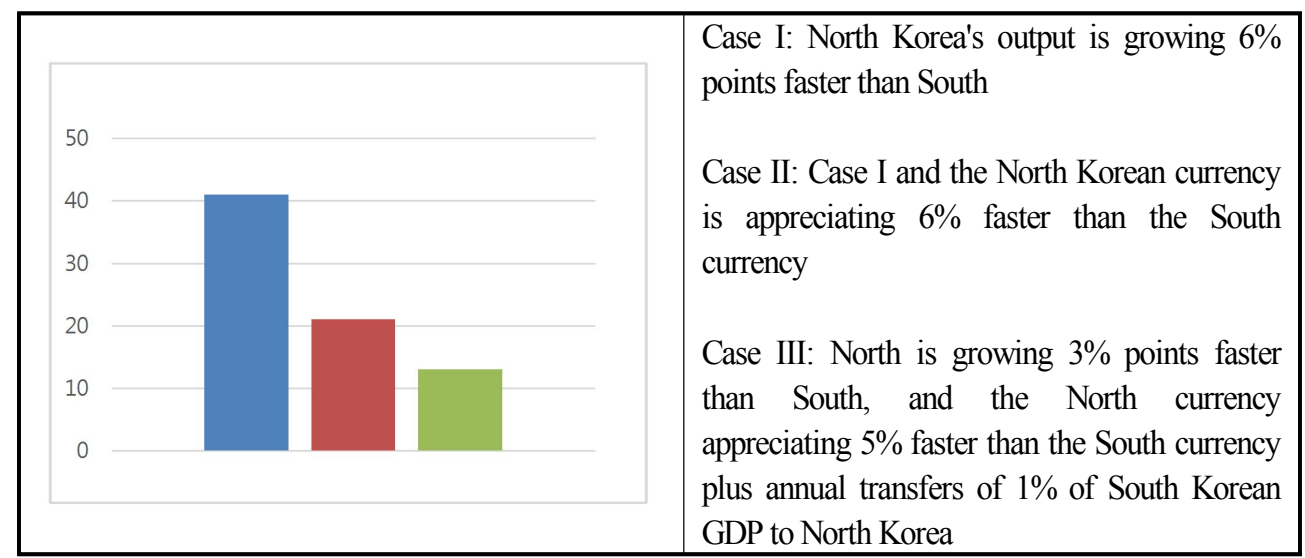

Source: Modified from the Exhibit 24 (p.20) of Goldman Sachs (2009)

Figure 1.

Illustrative scenario of a North-South income convergence

(Number of years for North Korea's per capita income to reach half of the South Korean level)

This optimistic conclusion was based on four main factors: (1) North Korea's labor force, (2) economic cooperation with South Korea, (3) economic gains from the transformation from a planned socialist system to a market economy, and (4) the growth potential of the mineral sector. The most critical element of these is the calculation of the 
benefits of unification in the mineral sector, achieved by breaking the economy of North Korea down into a mineral sector and a non-mineral sector.

The report states, "We convert the mineral wealth to financial assets equivalent to its NPV [net present value]. This effectively means that North Korea sells the mineral wealth to strategic investors at the NPV price and invests the proceeds in long-term bonds. We assume 3\% inflation-adjusted annual returns from the bonds through to 2050 . We also assume that North Korea earns $15 \%$ of mined minerals as wages paid by strategic investors." This represents Goldman Sachs' financial approach to Korea's unification as an international investment bank; it lacks a consideration of the structural problems in North Korea's industry and trade and ignores the prospect of changes in world mineral prices. Moreover, the Goldman Sachs report ignores the fact that economic gains compared with extraction costs differ across natural resources. In most cases, higher returns have been made for petroleum and gas, with poor performances for minerals such as manganese, zinc, and lead, in which North Korea is rich.

\subsection{Critical Analyses of Studies by Goldman Sachs and KIEP}

Considering the high costs of extraction, the low quality of minerals and ores, and the poor logistics infrastructure in North Korea, it was reported in KDI (2013) that the value of natural resources and labor forces was being overestimated. KDI (2013) states that "North Korea has rich mineral resources, but researchers can recognize that the value of these has been overestimated when more detailed assessment is made. It can be concluded that the development of natural resources cannot be a leading growth sector in North Korea, even though it has a high reservoir" (KDI 2013, pp. 9-10), here criticizing the argument of Goldman Sachs (2009, p.1) that "The conceptual framework is to convert the mineral wealth to financial wealth and estimate three sources of income: the converted financial assets, their investment returns, and wage income from mineral extraction."

Compared with Goldman Sachs (2009), KIEP employed a recursive CGE model that can incorporate industrial structures and trade issues including joining several FTAs under various scenarios. While the CGE model has many merits as an economic forecasting model, it requires a great deal of data and parameter information in running simulations. The heart of CGE estimation is the input-output (IO) table on which researchers base the analysis, with trade models incorporating the IO tables of all the relevant economies.

It seems that the KIEP researchers had problems in setting up the North Korean economy in the CGE model since North Korea has not published its IO tables and there is very limited information on its economy. KIEP adopted version 8.1 of the Global Trade 
Analysis Project (GTAP) database, which Purdue University has maintained since 1991. The GTAP database covers 129 countries/regions/economies, but North Korea could not be included. Because of this, KIEP needed to choose a country that is similar to North Korea in economic size and industrial structure.

According to KIEP (2014), Tanzania could be chosen as a proxy for the economy of North Korea, since the country is similar in economic size to North Korea and its major industry is the mining sector. However, KIEP (2014) tried to prepare a better proxy by selecting "Rest of East Asia" in the database, assuming that this region implicitly covers Macao and North Korea. KIEP (2014) wrote, "Since the economic size of Macao is small and the country trades heavily with China, most of Rest of East Asia in the GTAP database could be regarded as North Korea." However, the industrial structure of the Rest of East Asia is quite different to that of North Korea (Table 3) as estimated by the Bank of Korea in 2014. In addition to this, the GDP of the region is more than two times that of North Korea, which is about US\$30 billion as of 2013.

Table 3.

Industrial Structure of the Rest of East Asia

\begin{tabular}{c|r|r|r|r|r|r|r|r}
\hline Country/region & \multicolumn{2}{|c|}{$\begin{array}{c}\text { Rest of East } \\
\text { Asia }\end{array}$} & \multicolumn{2}{c|}{ Korea } & \multicolumn{2}{c|}{ China } & \multicolumn{2}{c}{$\begin{array}{c}\text { Other Developing } \\
\text { Countries }\end{array}$} \\
\hline Units & $\begin{array}{c}\text { Million } \\
\text { US\$ }\end{array}$ & $\begin{array}{c}\text { Share } \\
(\%)\end{array}$ & $\begin{array}{c}\text { Million } \\
\text { US\$ }\end{array}$ & $\begin{array}{c}\text { Share } \\
(\%)\end{array}$ & $\begin{array}{c}\text { Million } \\
\text { US\$ }\end{array}$ & $\begin{array}{c}\text { Share } \\
(\%)\end{array}$ & $\begin{array}{c}\text { Million } \\
\text { US\$ }\end{array}$ & $\begin{array}{c}\text { Share } \\
(\%)\end{array}$ \\
\hline $\begin{array}{c}\text { Agriculture, } \\
\text { forestry, } \\
\text { fishery }\end{array}$ & 3,011 & 4.44 & 59,255 & 2.59 & 547,030 & 5.64 & $1,958,851$ & 6.73 \\
\hline Mining & 2,218 & 3.27 & 5,233 & 0.23 & 280,152 & 2.89 & $2,053,870$ & 7.06 \\
\hline Light industry & 5,534 & 8.16 & 151,667 & 6.64 & $1,633,049$ & 16.84 & $2,911,957$ & 10.01 \\
\hline Heavy industry & 8,169 & 12.04 & 891,861 & 39.03 & $3,890,395$ & 40.11 & $6,080,883$ & 20.91 \\
\hline $\begin{array}{c}\text { Electricity, } \\
\text { gas, and water } \\
\text { supply }\end{array}$ & 2,215 & 3.26 & 45,970 & 2.01 & 275,525 & 2.84 & 956,434 & 3.29 \\
\hline Construction & 5,727 & 8.44 & 182,631 & 7.99 & 793,431 & 8.18 & $2,273,029$ & 7.81 \\
\hline Other services & 40,986 & 60.40 & 948,317 & 41.50 & $2,278,693$ & 23.50 & $12,852,476$ & 44.19 \\
\hline Total & 67,860 & 100 & $2,284,934$ & 100 & $9,698,274$ & 100 & $29,087,500$ & 100 \\
\hline
\end{tabular}

Source: Calculated from the data in the GTAP version 8.1 
Table 3 was calculated from data on industrial structures in the GTAP for Rest of East Asia, Korea, China, and "Other Developing Countries" for reference. The share of agriculture, forestry, and fishery of the Rest of East Asia is lower than that of China and Other Developing Countries, while that of other services including sales, food and lodging, transportation, real estate, telecommunications, banking, and insurance is much higher than that of Other developing countries. The point that Rest of East Asia cannot be equated with North Korea becomes clear when comparing the share of industries in Table 3 with the estimations made by the Bank of Korea as seen in Table 4.

Table 4.

North Korea's Industrial Structure

\begin{tabular}{|c|c|c|c|c|c|}
\hline & \multicolumn{3}{|c|}{ North Korea } & \multicolumn{2}{|c|}{ South Korea } \\
\hline & 2011 & 2012 & 2013 & 2012 & 2013 \\
\hline Agriculture, forestry, fishery & 23.1 & 23.4 & 22.4 & 2.5 & 2.3 \\
\hline Mining & 14.6 & 14.0 & 13.6 & 0.2 & 0.2 \\
\hline Light industry & 6.5 & 6.7 & 6.8 & 5.3 & 5.3 \\
\hline Heavy industry & 15.4 & 15.2 & 15.4 & 25.7 & 25.8 \\
\hline $\begin{array}{l}\text { Electricity, gas, and water } \\
\text { supply }\end{array}$ & 3.1 & 3.5 & 4.1 & 2.1 & 2.3 \\
\hline Construction & 7.9 & 7.8 & 7.8 & 4.8 & 5.0 \\
\hline Other services2) & 29.4 & 29.4 & 30.0 & 59.5 & 59.1 \\
\hline
\end{tabular}

Note: 1) Share of industrial production value out of nominal GDP

2) Other services include sales, food and lodging, transportation, real estate, telecommunications, banking, and insurance

Source: Restructured based on the data in Bank of Korea(2014) "Estimation on 2013 North Korean economy"

\section{A new approach for estimating Benefits and costs of Unification}

CGE models have been widely used for estimating the impact of economic integration. Since North Korea is one of the world's most closed economies in terms of international trade, an open trade policy in itself can bring substantial economic gains. Considering that a gradual unification will reduce unification costs and increase the benefits of unification, South Korea should promote such open policies in North Korea by demonstrating the economic gains that would follow from trade liberalization. For this, a simulation model will be necessary with correct data on North Korea. 
A key issue in building a CGE model for North Korea will be adequate data and information on its economy. Although no official IO table for North Korea is available, Korean researchers have tried to obtain North Korean IO tables based on piecemeal information derived from various sources. Shin (2010) and Choi (2014) are some of estimation studies of the IO table for North Korea. The contribution by Shin (2010) was to build a social accounting matrix (SAM) and to reflect the values of services in the North Korean IO table, noting that socialist countries do not account for the value of services in production, based on the materialist view prevailing under socialism.

"There is a limitation on the data collection of North Korea's inter-industry transaction, thus previous studies have used the representative method to the estimate IO table with incomplete information such as RAS and Entropy technique."4) (Choi 2014, p.30). Following previous studies, Choi (2014) attempts to estimate an IO table for North Korea based on various data such as the IO coefficient of the Vietnamese IO table, the industrial GDP ratio, and trade statistics. ${ }^{5}$ )

With the available estimates of SAM and IO tables for North Korea, a more accurate assessment of the benefits and costs of unification will be feasible via several methods, although this is beyond the scope of this survey paper and a follow-up research study will be undertaken. These tables can be used in building a CGE model for North Korea, with additional information required depending on the model structure. Since global CGE models require more data and information, a single-country CGE model will be desirable initially, which can be extended into the global context in the second stage.

Another approach will be to introduce the North Korean economy into the GTAP database as its 130th country, which would be a great contribution to this resource. This job could be undertaken individually or in collaboration with the GTAP administrators. Due to the lack of information, many parameters will have to be proxied or benchmarked from similar regions, although these will inevitably differ from the North Korean case. Since North Korea's IO table derived by Choi (2014) has only 7 sectors, it may be difficult for researchers to calculate the 57 sectors in the GTAP. For this, a series of strong assumptions will be necessary and some distortions may be expected during the conversion process.

4) The RAS method is a kind of bi-proportional iterative adjustment of data in rows and columns. The Entropy method is to balance the data using a matrix balancing technique.

5) The Vietnamese IO table was obtained for the early 2000s by the OECD, which considered the development stage of North Korea, industrial GDP ratios from the Bank of Korea, and trade statistics from Korea Trade-Investment Promotion Agency (KOTRA) and the Ministry of Unification. 


\section{Conclusion}

No one can be sure about the process of Korean unification, especially when considering the scenario of sudden collapse, but it is clear that a gradual unification will be most desirable in terms of the economic and political context. Thus, South Korea should encourage the most closed and poorest country in the world to become a part of the global economy. Political tension between the two Koreas needs to be softened by opening up dialogue. Moreover, trade and exchange between South and North Korea need to be improved. The symbolic cooperation in the Gaesung Industrial Complex should be expanded.

As for the assessment by the current government that unification could provide an economic windfall, there is no concrete study supporting this, and no clear consensus exists for the unification costs in Korea. The wide range of estimates needs to be narrowed and unification policy should be explored in order to reduce the costs of unification. "About $\$ 500$ billion would be needed to develop North Korea's economy over 20 years after reuniting, according to a report released this week by South Korea's Financial Services Commission. By contrast, the West German economy was 10-times larger than East Germany's when the Berlin Wall fell 25 years ago, the financial watchdog said. West Germany spent about \$2 trillion rebuilding a single country, some estimates show." (Bloomberg, November 21, 2014)

Policy-making bodies and national agencies need to understand the North Korean economy both qualitatively and quantitatively in order to produce more reliable estimates on the benefits and costs of unification. A CGE model for the North Korean economy will be a basic tool for decision making on unification policy. "Aside from the massive human and financial costs of the transition period, the duration of transition may also delay Korea's 'bonanza' $\cdots$ But conversations about the costs and benefits of unification must recognize tremendous uncertainty about the transition period - the dangers of which could have significant consequences for the political stability and economic potential of a unified Korea." (The Diplomat, February 23, 2015)6)

6) Viewed April 10, 2015 at http://thediplomat.com/2015/02/the-perils-of-korean-unification/ 


\section{References}

Bank of Korea(2014) "Estimation on 2013 North Korean economy"

Beck, Peter M. (2010), "Contemplating Korean Reunification”, The Wall Street Journal, January 4 (Retrieved 8 April 2015)

BusinessKorea(2015), "Effects of Unification", viewed on March 22, 2015 at http:/www.businesskorea.co.kr/article/6418/effects-unification-unification-korea-cr eate-us200-billion-economic-effects-surrounding\#sthash.slZt8LKW.dpuf

Chen, Lu and Theo Notteboom(2012), "Determinants for assigning Value-Added Logistics services to Logistics centers within a Supply Chain Configuration", Journal of International Logistics and Trade, Volume 10, No. 1

Cho, Dongho(2010), "Desirable discussion on the costs of unification" Jeju Peace Institute

Choi, Joonook(2011), How to finance unification costs?, Seoul: KIPF

Choi, Jiyoung(2014), "A study on estimation of the Input-output table for the North Korea economy”, BIKYOKYONGJAEYONGU Vol. 21, No. 2

Goldman Sachs (2009), "A United Korea? Reassessing North Korea Risks (Part I)", Goldman Sachs Global Economics

Hur, Yoon Jin, Solkey Lee and Jung Ung Min(2012), "Future Strategic Directions for TSR and TCR from the Perspective of the Northeast Asian Logistics Network", Journal of International Logistics and Trade, Volume 10, No. 1

Hyundai Research Institute (2009), Recent Trend in Development of North Korea's Mineral Resources and the Implications (in Korean), by Haejung Lee

Kim, Sukjin, Sukgi Lee, Kaehwan Kim and Doohee Lee (2008), Industrial development strategy based on the experience of transition economies, Seoul: KIET 
Kim, Changguen(2014), "Economic performance of German unification and research trend in German unification", JRI Research Series 4

KINU(2011), "New approach on the benefits and costs of unification: Comprehensive research factor and the search for alternative approach", Comprehensive research on the benefits and costs of unification, Vol. 11, No. 1

Korea Development Institute (KDI, 2010), "Future vision 2040", presented at the Future Planning Committee, $7^{\text {th }}$ meeting

KDI(2013), A Study on Economic Integration between South Korea and North Korea: Long-term development strategy for North Korea

Korea Institute of International Economic Policy (KIEP, 2014), "Effects of Economic Integration between South Korea and North Korea", July.In Korean.

Lee, Kwangsik and KownsikKim(2012), "Analysis on the studies on unification: BC of unification costs and the network of unification policy", Public policy and administration of national agenda, Vol. 6, No. 2, Dankook University

Lee, Seung Hyun and Kim, Kap-sik(2011), "The Issues and Alternatives on the Reunification Cost of the Korean Peninsula", Policy Studies, Winter 2011

Lee, Youngsun(1992), "Scenario approach for the economic effects and BC analysis of unification in Korea", Seoul, Institute of East and West Studies, Yonsei University

Leontief, W.(1936),"Quantitative Input and Output Relations in the Economic Systems of the United States",The Review of Economics and Statistics, pp.105-125.

Noland, M. (1996)."Some unpleasant arithmetic concerning unification" (No. 96).Institute for International Economics.

Noland, Marcus, Sherman Robinson, and Li-Gang Liu(1997), "Calibrating the Costs (and Benefits) of Unification." Korean Economic Integration, Washington: Institute for International Economics 
Marcus Noland, Sherman Robinson, Li-Gang Liu(1998), "The Costs and Benefits of Korean Unification", Working Paper 98-1, Peterson Institute for International Economics

Park, Sungjo(2014), "The process of German unification and implications for Korea" presented at JRI seminar(May, 2014)

RAND(2005), National Defense Research Institute, North Korean ParadoxesCircumstance, Costs and Consequences of Korean Unification, by Wolf, Charles

SERI(2005), "North Korean economy and current state of South-North economic cooperation", CEO information.

Shin,D.C.(2009), "The Estimation and Analysis for the North Korean Economy,"

Shin, Changmin(2010), "Costs of unification and its benefits", KINU Seminar Proceeding 10-03, Seoul: KINU

Sung, Hankyung(2014), "The analysis of costs and benefits of unification in Korea under various scenarios", presented at the seminar organized by KIEP (Lotte Hotel, November 5)

The Diplomat(2015), “The Perils of Korean Unification”, February 23

Wolf, Charles(2010), “The Cost Of Reuniting Korea”, Forbes, March 15

Wolf, Holger "Korean unification: Lessons from Germany" Peterson Institute for International Economics.(Retrieved from www.piie.com November 19 2014)

Zang, Hyoungsoo(2011), “A New Look on Korean Unification and It’s Financing Issues”, Policy Studies, Winter 2011 